\title{
THE HISTORY OF THE SCHOOL CAMPUS IN CHECHNYA (1920S)
}

(C) 2017

Matagova Khatmat Abuevna, candidate of historical sciences, associate professor of Russian History and Political Science Department Chechen State University (Grozny, Russian Federation)

Abstract. The paper attempts to characterize the history of the school campus, which is one of the specific forms of national personnel training in the Chechen Autonomous Region in the 1920s. In the first Soviet decades considerable attention was paid to the problems of education in the national outskirts. The low level of literacy of the population of Chechnya, inherited from the past, led to the features of processes occurring in the field of education and culture. The lack of the required number of national personnel and the need for their concentration in one area to serve simultaneously several academic units led to the organization of Lenin campuses. In 1925 in Chechnya an education city was organized that united a pedagogical college, an agricultural school of the Soviet party school and a school with a total combined educational and economic part. By 1930 there had been changes in the structure of the school campus, which included by that time a reference school (four-year stage 1), a cooperative vocational school, oneyear training courses in technical school, agricultural training. Teachers college was not included in the school campus by that time. The training campus in Chechnya trained thousands of party and Soviet, trade Union, Komsomol and farm workers and was an important link in the education system of the Chechen Republic.

Keywords: Chechen Region; Soviet government; education system; national staff; training camp; teachers college; Soviet party school; secondary school.

УДК 930.2

Статья поступила в редакцию 05.09.2017

\section{ДЕЯТЕЛЬНОСТЬ ТЕАТРОВ НА ЮЖНОМ УРАЛЕ В НАЧАЛЬНЫЙ ПЕРИОД «ОТТЕПЕЛИ»} (C) 2017

Морозова Ирина Павловна, учитель истории и обществознания Лицей № 2 (г. Оренбург, Российская Федерация)

Аннотация. В работе рассматриваются проблемы развития театральной деятельности на Южном Урале в начальный период «оттепели». Цель исследования - определить, какие изменения происходили в театральной деятельности на Южном Урале после сталинских репрессий в 1953-1964 годах ХХ века. При написании работы использовались материалы периодической печати, архивные документы, книги о театральном искусстве. Исследование показало, что после разоблачения культа личности Сталина произошли большие изменения в театральном искусстве Южного Урала. Театральное искусство становится более востребованным в народе. Именно в Башкирии театральное искусство развивается быстрыми темпами.

В представленной статье исследована творческая деятельность театров в определенных территориальных рамках (Южный Урал, Оренбургская область и Башкирия), определены специфические черты и проблемы функционирования изучаемых учреждений в эпоху «оттепели», изучена репертуарная политика театров. Выявлено, что обновляется репертуар, открываются новые театры. Актёры, режиссёры, при ослабевающей политической цензуре, находят новые формы художественного самовыражения. Драматическое искусство перестаёт быть оружием политической пропаганды.

Автор не имеет возможности провести сравнительный анализ своей работы с другими исследованиями по данной теме, так как данная тема никем не исследовалась.

Ключевые слова: театр; театральное искусство; театральная деятельность; театральный репертуар; гастрольная деятельность театров; посещаемость театральных мероприятий; художественное творчество; театральные общества на Южном Урале; драматическое искусство; художественное самовыражение; театральное искусство; драматический театр; драматург; гастрольные афиши; режиссерский замысел; сценическое воплощение; областной театр; творческий путь.

Театральная деятельность на Южном Урале в 1953-1964 годах развивалась неравномерно. Социалистический реализм рождается из честного творчества художника, проникнутого социалистическим мироощущением. Основой социалистического реализма является мировоззрение художника. Оно может быть выражено различными способами, но должно вызывать у зрителя переживание, созвучное эпохе [1, с. 177]. Развитие советского искусства и метода социалистического реализма стало тормозиться процессом, впоследствии квалифицированном как культ личности И.В. Сталина Вождь воспринимал советское государство как машину, как механизм. Имея неограниченную власть, он допускал жесткий произвол, подавляя человека. Создавалась такая обстановка, при которой человек не мог проявлять свою волю.

Искусство, поставленное на службу партийного аппарата, способствовало «идеологическому воспитанию масс» [2, с. 437]. Все виды искусства - литература, кино, живопись, театр - воспевали производство. Человек изображался только в своей функциональной сущности: шахтёр, врач, учёный. [3, с. 437]. В центре любого художественного произведения производственный конфликт, завязанный на смене технологий при необходимости улучшения управления [2, с. 437]. Сталинский социализм - это не человеческое общество, а огромная фабрика, где всё разумно устроено. Культуре в этом обществе отводится утилитарная роль - оправдание сложившейся си- 
стемы. Мировоззрение подавляющего большинства советских деятелей искусства стало соответствовать официальной идеологии, большинство произведений того времени открыто носило характер пропаганды [2, c. 435].

В 1954 году вышел в свет роман И. Эренбурга «Оттепель», вызвавший большой интерес в обществе. Название книги становится нарицательным, своеобразным символом духовного раскрепощения людей после сталинского периода. Работа XX съезда КПСС, доклад Н.С. Хрущёва «О культе личности и его последствиях», специальное Постановление ЦК КПСС от 30 июня 1956 года, развенчавшего «культ личности Сталина», реабилитация миллионов ни в чём не повинных людей - всё это имело чрезвычайно важные последствия для духовной жизни общества [4, с. 807].

В деятельности Министерства культуры и Отдела культуры ЦК происходили перемены. Популярными лозунгами стали «восстановление ленинских норм партийно-государственного руководства» и «преодоление последствий культа личности». Расширяя самостоятельность творческих союзов, партийное руководство собиралось возложить на них задачи идеологического контроля [5].

Театр для советского человека периода «оттепели» стал обладать своеобразным правом выносить на общественное обсуждение самые сложные вопросы, привлекать к ним общественное внимание, настраивать людей на решение тех или иных задач, которые вставали перед обществом и жизнью [6].

В Чкаловской области ведущим театром считался Чкаловский областной драматический театр имени М. Горького, который к 1953 году благодаря главному режиссёру М.А. Куликовскому характеризовался как «крепкий ансамбль опытных мастеров и молодых актёров, режиссёров и художников, объединённых общей задачей создания интересного и большого театра» [7, с. 142-143]. Однако, несмотря на яркий, достойный внимания репертуар, театр строго контролировался системой. Каждый спектакль, прежде чем войти в текущий репертуар, должен был получить разрешение специальной комиссии, которую возглавляла уполномоченная ГУРК по Чкаловской области К. Деснер.

В 1953 году Юрий Самойлович Иоффе продолжил «ваяние творческого лица» чкаловского театра. Очень робко процесс десталинизации происходит в театрах. Репертуар этих лет носит идеологизированный характер, герои схематичны, сюжеты надуманы, а оценка игры актёров в прессе подвергается критике. Так, например, К. Надеждина в статье «Девичий переполох» пишет: «Наряду с несомненными достоинствами, правильным исполнением ряда ролей, сильной музыкальной частью, в спектакле есть элементы злоупотребления внешней стороной «игры на публику», потеря чувства меры» [8].

Продолжается жёсткая система контроля со стороны партийных органов. Газета «Советское искусство» от 7 апреля 1953 года пишет: «Чкаловский областной драматический театр имени М. Горького осуществил постановку спектакля местного автора В.А. Пистоленко « Емельян Пугачёв». Обком КПСС оказал большую помощь театру и автору. В процессе работы спектакль обсуждался в отделе пропаганды обкома КПСС, было созвано собрание историков, давших ряд ценных указаний» [9]. На премьеру пьесы Е. Успенской и Л. Ошанина «Твоё личное дело», состоявшуюся в мае 1953 года на сцене Чкаловского драматического театра, отозвались несколько авторов. В статье «Твоё личное дело» М. Климов пишет: «Тема пьесы - большая важная, волнующая: борьба за моральную чистоту советского человека. Поведение коммуниста в быту не является только его личным делом».

С 1952 по 1954 год театр поставил 21 пьесу. В период с 1955 по 1963 г. - 89 пьес. За период с 1953 года по 1964 год театр побывал на гастролях: в Москве в 1955 году, в г. Эмба (Казахстан) в 1958 году, в 1959 году в Ленинске (Казахстан), в 1960 году в Куйбышеве, в 1962 году в Москве, в 1963 году в Бугуруслане, Бузулуке (Оренбургская область), в 1964 году в Уфе [7, с. 148-149].

В январе 1956 года на сцене Чкаловского драматического театра идёт пьеса В. Розова «В добрый час» в постановке заслуженного артиста Казахской ССР и УзССР Ю.С. Иоффе (художник Д.Н. Фомичёв, ведущие актрисы спектакля Е.Н. Агеева, В.А. Кашина). В прессе сразу появляется отклик: «...В новой комедии драматург ставит важные вопросы формирования, воспитания характера, роли среды в процессе становления личности. Пьеса о счастье, о дружбе и любви. Перед зрителями предстают герои, у каждого из которых свой характер, своя цель, своя мечта. И это не отвлечённые мёртвые схемы, а живые люди с хорошими и плохими сторонами их натуры», - пишет Ю. Павлов [10].

Чкаловский драматический театр, накопивший немалый опыт, успешно показавший себя перед местным зрителем, впервые выезжает в Москву летом 1955 года. Первые гастроли перед искушённым столичным зрителем стали настоящим экзаменом для всего творческого коллектива театра. В гастрольной афише были представлены постановки режиссёров: Ю.С. Иоффе - «По велению сердца» Н. Анова; Я. Штейна - «Царь Фёдор Иоанович» А. Толстого; «Любовь Ани Берёзко» В. Пистоленко, «Дачники» М. Горького; И.Ф. Щегловой - «Дикарка» А Островского; «Емельян Пугачёв» В. Пистоленко; «Дон Сезар де Базан» Дюмануара и Деннери; М.В. Нагли «Персональное дело» Я. Штейна.

Столица признала большой творческий потенциал театра [7, с. 150-151]. В работе Чкаловского театра отмечено «стремление к ясности и определённости режиссёрского замысла, к предельной яркости всех выразительных средств, смелости красок в обрисовке характеров». О художниках - оформителях спектаклей подмечено, что «они тонко ощущают стилевую природу автора и режиссёрский замысел, находят оригинальные и смелые решения для каждого спектакля, умело и продуктивно разрабатывают сценическую площадку». Отмечено, что режиссёры Ю. Иоффе, И. Щеглова, М. Нагли «добиваются правды, яркости сценического воплощения путём вдумчивого, глубокого раскрытия психологических тонкостей, сложностей в содержании произведений, в отношениях героев», а «театр всегда выходит победителем ... когда идёт к яркой театральности через глубокий анализ жизненных явлений, через большую жизненную правду» [11]. 
Талантливый режиссёр Ю.С. Иоффе обращается к местному материалу. В столетнем юбилейном репертуаре Чкаловского драматического театра есть одна особенность: из 12 пьес, включённых в этот сезон, три принадлежат перу местных драматургов или написаны на местном материале. По идее Иоффе была специально написана Н. Ановым пьеса «Оренбургская старина». Пьеса посвящена далёкому прошлому Оренбурга и рассказывает о борьбе его лучших представителей за создание в городе театрапросветителя. При большом участии режиссёра была создана ещё одна пьеса, которая получила путёвку в большую сценическую жизнь - «Любовь Ани Берёзко» В. Пистоленко. Здесь же впервые осуществлена постановка первой в стране пьесы о новосёлахцелинниках «По велению сердца» Н.И. Анова и Я. Штейна [12].

Не отстают от главного областного театра и другие театры. К середине 50-х годов Бугурусланский городской драматический театр в поисках своего творческого пути живёт напряжённой творческой жизнью. Репертуар его составлен довольно интересно. Это «Хрустальный ключ» Е. Бондаревой, «Любовь Ани Берёзко» В. Пистоленко, «В добрый час» В. Розова, «Возвращение» А. Кузмичёва, «Персональное дело» А. Штейна, «Омут» Э. Фабра (по Бальзаку), «Не всё коту масленица» А. Островского, «Несчастный случай» М. Маклярского и Д. Холендро, «Мартын Бородуля» И. Тобилевича, «Семейное дело» Е. Литовского. Новые направления в театральном искусстве быстрыми темпами завоёвывали любовь и признание среди советского народа. Театр становится отрадой в непростые моменты человеческих жизней, помогает обрести силы в трудные минуты, подсказывает пути решения жизненных проблем, начинает служить средством самовыражения для многих людей. Театральное творчество становится отправной точкой, импульсом для появления так называемых самодеятельных театров. Такие самодеятельные театры появляются в учебных заведениях, на заводах, при домах культуры, в сельских клубах. Так, например, 16 апреля 1956 года в областном театре музыкальной комедии состоялся студенческий вечер, на котором театральный коллектив мединститута показал спектакль «Шутники» А.Н. Островского, который тепло встретили зрители [13].

В этом же году в областном центре состоялся смотр художественной самодеятельности. В зале присутствует заслуженный артист Чкаловского драматического театра В. Агеев. На сцене - любители драматического искусства. Хорошо была исполнена пьеса «Женатый холостяк» театральным коллективом Абдулинского железнодорожного клуба, женская средняя школа представила пьесу «Шляпа», Дом культуры металлургов Орска показал пьесу «Не называя фамилий», клуб «25 лет Октября» посёлка Никитино города Медногорска показал пьесу А. Кумичёва «Возвращение», написанную на тему семьи и семейных взаимоотношений [14].

Театральный самодеятельный коллектив Дома культуры Чкаловского паровозоремонтного завода один из старейших в городе - показал новый спектакль по драме Е. Бондаревой «Хрустальный ключ».
Действие разворачивается на одной из дальних застав. В пьесе имеется острый сюжет, но главное внимание автора направлено на раскрытие человеческих характеров, духовного мира людей. Постановщику К. Миронову удалось создать интересный спектакль с хорошим юмором и яркими драматическими моментами. Исполняли роли рядовые работники завода: служащий, столяр, мастер, слесарь, медсестра, даже домохозяйка. Несмотря на недостатки в режиссуре, для культуры это - безусловно хорошая работа [15].

В это время всё чаще проходят творческие встречи актёров и зрителей, на которых обсуждаются спектакли, оценивается игра актёров, премьеры. Становятся нормой постоянные гастрольные спектакли на селе, в малых городах области, на степных площадках целинных станов. Так, газета «Советская культура» пишет: «Орский театр драмы имени А.С. Пушкина выпустил две премьеры: «Иван Рыбаков» В. Гусева и «Забытый друг» А. Салынского. Новые спектакли будут показаны труженикам целинных земель Чкаловской области. Театр побывал в 15 целинных совхозах, дано 60 спектаклей» [16].

$\mathrm{He}$ менее интересна история театральной деятельности Башкортостана. Современный Башкирский академический театр драмы имени народного поэта Башкортостана Мажита Гафури был учреждён постановлением Большой коллегии Башкирского народного комиссариата просвещения (БНКП) 4 декабря 1919 года в Стерлитамаке под названием «Первый Башкирский государственный театр». Как и все театры советского социализма, он проходил все этапы развития: от великого творческого успеха в 2030-е годы до жесточайшего сталинского террора.

В 50-60-е годы XX века на художественный облик национальной сцены оказала огромное влияние заслуженный деятель искусств РСФСР и БАССР, лауреат Государственной премии РСФСР им. К.С. Станиславского Шаура Мусовна Муртазина. Заслуженная артистка БАССР, народная артистка БАССР, заслуженная артистка РСФСР Бэдэр Ахметовна Юсупова, проработавшая в театре актрисой полвека, говорила: «Театр нужно любить преданно и нежно» [17]. Именно так любила театр она сама [18]. Труппу театра составляли маститые мастера сцены: Гази Гирфанович Галимов-Бухарский - актёр, режиссёр, народный артист БАССР, заслуженный артист РСФСР, заслуженный деятель искусств БАССР [19], Елизавета Александровна Шляхтина-Сыртланова актриса, режиссёр, заслуженная актриса БАССР [20], Газим Мутагарович Тукаев - заслуженный артист БАССР, народный артист БАССР, заслуженный артист РСФСР, народный артист РСФСР [21]. После сталинских репрессий театр утратил единую линию развития. Шаура Муртазина понимала, что театр не может развиться без активного взаимодействия с другими культурами и что только общение с ними наполнит и обогатит собственное видение, собственное искусство. Ею осуществлены постановки «Последняя жертва» А. Островского (1950 г.), «С любовью не шутят» П. Кальдерона (1951 г.), «Виндзорские насмешницы» (1953 г.), «Дядя Ваня» (1954 г.), «Чайка» (1960 г.) А. Чехова, «Кража» Д. Лондона 
(1955 г.), «У этой женщины свои законы» по пьесе Э. де Филиппо «Филумена Мортурано» (1958 г.). Характерно, что её творческие устремления связаны с реализацией классического репертуара, она автор оригинальных сценических прочтений русской и западноевропейской классической драматургии [22].

В 1957 году Башкирский академический театр показал спектакль «Муса Джалиль». Пьеса написана одним из видных драматургов Советской Татарии Н. Исанбетовым. Автор взял лишь определённый период жизни поэта. Характер героя раскрывается с наибольшей полнотой. Пьеса Исанбетова - не просто произведение о самоотверженном человеке. Рамки его гораздо шире. В характере Мусы Джалиля отражается гуманистический пафос, подвиг советского человека, утверждение высокой человеческой морали. Большую работу проделал коллектив театра, создавая спектакль. Режиссёр, заслуженный артист БАССР Р. Файзуллин совместно с автором улучшил пьесу, сделал её более компактной, целеустремлённой [23].

После длительного перерыва 1 марта 1957 года вновь открыт Башкирский театр оперы и балета. Театр открыл сезон оперой великого русского композитора А. Бородина «Князь Игорь». В новом театральном сезоне показаны 5 спектаклей. Работоспособный, творческий коллектив приложил все усилия, создавая спектакли [3].

Башкирский театр оперы и балета осуществил постановку оперы П.И. Чайковского «Чародейка». Нравственную красоту, большую силу любви подчёркивает в образе Настасьи молодая артистка Шагизиганова [24].

Драма С. Алёшина «Одна», поставленная Уфимским русским драматическим театром, отличается остротой в изображении психологической сложности современного бытового конфликта. В прессе она названа «Драмой о любви и честности». Автор не навязывает выводов, а заставляет самих зрителей подумать: могли ли герои поступить иначе, чем они поступили, и возможно ли для них счастье. Спектакль этот удался благодаря вдумчивому прочтению «спорной» пьесы Алёшина [25].

Мустай Карим - выдающийся башкирский поэт, драматург - оказал огромное влияние на духовную жизнь современников, в первую очередь своего народа, на языке которого он мыслил, говорил и писал. В творчестве драматурга прослеживаются отдельные хронологические циклы. С 1947 по 1960 годы написаны пьесы «Свадьба продолжается», «Одинокая берёза», «Похищение девушки», «Неспетая песня». В сложное время хрущёвской «оттепели» была написана пьеса «В ночь лунного затмения» и поставлена в1964 году на сцене Башкирского академического театра драмы. С одной стороны, пьеса была сугубо национальная, изображающая историческое прошлое народа, с другой стороны, М. Карим бытовую драму возвёл в высокую трагедию, в которой судьба человека становится судьбой народной [26, с. 108].

«Оттепель» способствовала бурному развитию культуры. Уже к середине 50-х театральное искусство становится более востребованным, поскольку начинает отражать социальные настроения общества того периода. Постепенно начинает ослабевать политический контроль со стороны власти, драматиче- ское искусство перестаёт быть оружием пропаганды и становится просто искусством. Театр развивается быстрыми темпами, избавляясь от пережитков сталинской эпохи, приобретая черты более реалистичного, отвечающего интересам зрителя. Почувствовав веяние свободы, драматурги, режиссёры, актёры стремились к новым формам художественного самовыражения, так долго пребывавшего под запретом.

\section{СПИСОК ЛИТЕРАТУРЫ:}

1. Мухина В. Литературно-критическое наследие: Т. 1-3. М.: Изд. «Искусство», 1959-1960.

2. Семенникова Л.И. Россия в мировом сообществе цивилизаций. Брянск: Изд-во «Курсив», 2000 г. 539 c.

3. Оперный театр открыт // Советская Башкирия. № 51 от 2.03.1957 г. С. 4.

4. Аппарат ЦК КПСС и культура. 1953-1957 / Общ. ред. и сост. В.Ю. Афиани. М.: Росспэн. 2001. $805 \mathrm{c}$.

5. О преобразовании министерств СССР: Закон СССР от 15 марта 1953 г. // Ведомости Верховного Совета СССР 1953. № 3. С. 11.

6. Быков Р.А. Театр - это театр // Театр. № 6 от 1959. С. 7.

7. Рябцева М. Оренбургские театральные сезоны. Изд-во Оренбург, 2015. 488 с.

8. Девичий переполох // Чкаловская коммуна. № 18 от 22.01.1953. С. 4.

9. Из редакционной почты // Советское искусство. № 26 от 7.04.1953. С. 3 .

10. В добрый час // Чкаловская коммуна. № 6 от 8.01.1956. С. 4.

11. Залог успеха // Советская культура. № 112 от 10.09.1955. C. 3 .

12. Оренбургская старина // Чкаловская коммуна. № 41 от 17.02.1957. С. 3 .

13. В студенческом театральном коллективе // Чкаловская коммуна. № 91 от 19.04.1956. С. 3.

14. На сцене - любители драматического искусства // Чкаловская коммуна. № 7 от 10.01.1956. С. 4.

15. «Хрустальный ключ» на сцене Дома культуры // Чкаловская коммуна. № 160 от 12.07.1956. С. 3.

16. Театральная хроника // Советская культура. № 61 от 26.05.1956. С. 3 .

17. Театр надо любить // Советская Башкирия. № 228 от 27.09.1990. С. 4.

18. Национальный архив Республики Башкортостан (далее - НА РБ). Ф. 1352. Оп. 4. Д. 1. Л. 1.

19. НА РБ. Ф. 1352. Оп. 4. Д. 1. Л. 2.

20. НА РБ. Ф. 1352. Оп. 4. Д. 1. Л. 3.

21. НА РБ. Ф. 1352. Оп. 4. Д. 1. Л. 4.

22. Сагитова А. Мастер башкирской режиссуры // Диалог культур и тюркоязычный театр: мат-лы междунар. науч.-практ. конф. (7 сентября 2012 г.). Уфа, 2012. C. 123-134.

23. Спектакль о поэте-герое // Советская Башкирия. № 79 от 04.04.1957. С. 4.

24. Чародейка // Советская Башкирия. № 84 от 10.04.1957. C. 4.

25. Спектакль о любви и о честности // Советская Башкирия. № 61 от 14.03.1957 г. С. 3.

26. Кусимова С. Послание миру. Феномен «театра Мустая Карима в контексте Башкирской сцены» // Ватанлаш. 2014. № 8. С. 63-77. 


\title{
THEATRE ACTIVITY IN THE SOUTHERN URALS AT THE INITIAL PERIOD OF THE THAW
}

(C) 2017

\author{
Morozova Irina Pavlovna, teacher of history and social theory \\ Lyceum №2 (Orenburg, Russian Federation)
}

Abstract. The paper deals with the problems of theatre activity development in the southern Urals at the initial period of the thaw. The research objective is to define what changes happened in the theatre activity in the Southern Urals after Stalin's repressions in 1953-1964. For the research the author used periodicals, archival documents, books about the theater. The research has shown that after Stalin's personality cult exposure there were big theater changes in the southern Urals. People became more interested in the theatre. It was in Bashkiria where the theater developed greatly. The paper examines the creative activity of theatres in the southern Urals, Orenburg Region and Bashkortostan, reveals specific features and problems in the functioning of the studied institutions in the era of the thaw, studies repertoire policy of theaters. The repertoire updated and new theaters opened. Actors and directors found new forms of art self-expression. Drama art stops being the weapon of the political propaganda. The author has no opportunity to carry out a comparative analysis of this research with other researches as the subject has not been investigated by anybody yet.

Keywords: theatre; theatre arts; theatre activities; theatrical repertoire; touring theatres; attendance at theatrical events; art; theatre companies in southern Urals; acting; artistic expression; theatre; drama theatre; playwright; tour posters; Director's vision; staging; regional theater; creative way.

УДК 94

Статья поступила в редакцию 25.08.2017

\section{ВНЕШНЯЯ ПОЛИТИКА США В ПОСЛЕДНЕЙ ЧЕТВЕРТИ ХІХ - НАЧАЛА ХХ ВЕКА И СОЦИАЛ-ДАРВИНИСТСКАЯ ИДЕОЛОГИЯ}

(C) 2017

\author{
Мухатаев Павел Николаевич, учитель истории и обществознания \\ Средняя общеобразовательная школа № 7 г.о. Самара (2. Самара, Российская Федераџия)
}

Аннотация. В данной статье представлен краткий обзор историографии внешней политики Соединенных Штатов Америки, а также анализ причин возникновения экспансионистской парадигмы США конца XIX начала XX века. Обширная советская историография дает представление об экономическом аспекте событий в США в указанный период, у зарубежных авторов более многомерное представление о происходивших событиях. А. Шлезингер, например, заявлял о второстепенности экономических причин активной внешней политики Соединенных Штатов Америки, указывая политические причины первостепенными. Социалдарвинизм как явление, формировавшее внешнюю политику, рассматривается историками лишь косвенно. В российско-советской историографии социал-дарвинизм обозначается как некий фактор, опосредованно влиявший на политику. Американская историография более цельно рассматривает предмет нашего исследования, но в контексте анализа либеральной идеологии. Автор статьи указывает на роль идеологических причин принятия руководством Соединенных Штатов Америки внешнеполитических решений. В статье делается попытка выяснить, существовала ли связь активной внешней политики с социал-дарвинистским дискурсом, который прослеживается и у сторонников данного курса, и у ее противников в политических, экономических и интеллектуальных элитах американского общества на рубеже веков.

Ключевые слова: социал-дарвинизм; внешняя политика США конца XIX - начала XX века; Г. Спенсер; А. Беверидж; К. Шурц; Ч. Конант; А. Мэхен; Ф. Тернер; Э. Карнеги; Т. Рузвельт; англосаксонская раса; Г. Зинн; А. Шлезингер; Б.Д. Козенко; А.П. Раскин; Г.И. Мусихин; А.Б. Гофман; экспансионизм.

Внешняя политика Соединенных Штатов Америки в конце XIX - начале XX века характеризуется многими историками как «экспансионистская».

После Гражданской войны и Реконструкции в США бурно развивалась экономика, для которой внутренний рынок Соединенных Штатов становился недостаточным для реализации своих амбиций и возможностей. Эти процессы очень хорошо описаны советскими историками, например, в четырехтомнике Истории США [1]. Преодоление связанных с этим проблем, например перепроизводства и экономической депрессии, было связано с активной внешней политикой США.

В последней четверти XIX века правительство Соединенных Штатов Америки стало смотреть за пределы собственных территорий. В 1880-90-е годы XIX века руководство страны активно наращивало военно-морской потенциал. К 1893 году морской флот Соединенных Штатов по своим возможностям вышел на пятое место в мире, и этот рост продолжался с еще большей энергией в начале XX века при президенте Т. Рузвельте [1, с. 149; 2, с. 258-278]. Наращивание военной силы не прошло бесследно. В 90-е годы XIX века к Соединенным Штатам Америки были присоединены Гавайские острова, которые, по мнению историков, укрепляли позиции США в Тихом океане и способствовали продвижению американских интересов на Восток Азии [3]. В 1898 году произошла война с Испанией, владеющей о. Куба и рядом островов в Тихом океане. Причем война началась с трагедии на броненосце «Мэн», которая, согласно исследованиям, была не до конца расследована и являлась предлогом для начала войны $[4$, c. 333$]$. 